\title{
PENGEMBANGAN KEMAMPUAN INDUSTRI KREATIF VIDEO DI KAMPUNG KOTA
}

\author{
Obed Bima Wicandra ${ }^{1}$, Erandaru ${ }^{2}$, Gunawan Tanuwidjaja ${ }^{3}$ \\ Budi Prasetyadi ${ }^{4}$, Linda Octavia ${ }^{5}$ \\ 1,2,4,5)Fakultas Seni dan Desain, Program Studi Desain Komunikasi Visual, \\ Universitas Kristen Petra \\ Jl. Siwalankerto 121-131, Surabaya 60236 \\ E-mail: obedbima@petra.ac.id, andar@petra.ac.id, budipras66@yahoo.com, linda2010_arch@yahoo.com \\ 3)Fakultas Teknik Sipil dan Perencanaan, Program Studi Teknik Arsitektur, \\ Universitas Kristen Petra \\ Jl. Siwalankerto 121-131, Surabaya 60236 \\ E-mail: gunte@petra.ac.id
}

\begin{abstract}
Abstrak: Artikel ini untuk mendeskripsikan mengenai kegiatan pengabdian masyarakat yang telah dilakukan oleh tim dari Desain Komunikasi Visual dan Arsitektur UK Petra dengan dukungan penuh dari LPPM UK Petra. Kegiatan utama ini berupa pelatihan dan pemutaran film bersama masyarakat yang merupakan komunitas Bratang Tangkis. Sasaran pengabdian masyarakat ialah warga yang tinggal di Kampung Bratang Tangkis, Barata Jaya dan Kendangsari. Pemilihan warga ini ialah karena kerjasama dari Platform Ayorek! antara Universitas Kristen Petra dan Paguyuban Warga Strenkali Surabaya. Warga memiliki kebutuhan untuk mendokumentasikan potensi lingkungan pada kampung Bratang Tangkis secara partisipatif. Kegiatan ini terkait dengan pengembangan ekonomi lokal dan seiring dengan strategi pengembangan ekonomi kreatif secara nasional. Untuk materi pelatihan dilakukan shooting video kampung secara partisipatif. Objek yang di-shooting ialah pernikahan dan peristiwa penting di kampung. Kemudian dilakukan pelatihan untuk transfer video dan editing video.
\end{abstract}

Kata kunci: Video, pernikahan, sejarah kampung.

\begin{abstract}
This article provides description of public services project carried out by the Petra's Department of Architecture and the Department of Visual Communication Design under the full support from Petra's Research \& Public Service Institution. The main activities of this project are video production training and video screening for Bratang Tangkis community. The main target for this project is people living in the Kampung of Bratang Tangkis, Barata Jaya and Kendangsari. They were chosen as a result of PCU collaboration with The Residents of Surabaya's River Bank Community within the platform of Ayorek! The residents feel the need to proactively document their living environment potential, an activity that is related with the development of local economy and in-line with the nation's strategy to develop creative economy. The training material is performing participative video recordings of wedding ceremonies and traditional events that took place within the kampung, followed with training on video transfer and editing.
\end{abstract}

Keywords: Video, wedding, kampung history.

\section{PENDAHULUAN}

Kampung yang berada di pinggir sungai Kali Mas, Surabaya atau biasa disebut sebagai stren kali sering dipandang sebagai kawasan yang kumuh dan mendapat stigma sebagai penyebab lingkungan yang tak sehat. Namun berbeda dengan kawasan kampung Bratang Tangkis yang dalam beberapa tahun terakhir ini sibuk membenahi dirinya agar mendapat penilaian positif dari masyarakat di luar stren kali maupun pemerintah kota Surabaya. Hal ini tak lain sebagai upaya untuk meyakinkan pemegang kebijakan ruang kota agar huniannya tidak tergusur maupun dimarjinalisasikan

Gambaran kampung Bratang Tangkis tampak berbeda, karena kearifan lokal warganya untuk membangun kawasannya secara swadaya dan 
kreatif. Perkembangan fisik ini ternyata juga diikuti oleh perkembangan sosial ekonomi masyarakatnya. Kehidupan warga yang mayoritas bekerja disektor informal, mereka juga berorganisasi dalam Paguyuban Warga Strenkali Surabaya (PWSS) untuk memperjuangkan kepastian hukum dari tanah kampung ini, menata kampungnya secara partisipatif dan mandiri Organisasi ini juga mendorong warganya untuk mengembangkan kebiasaan positif untuk menjaga kali atau "jogo kali”. Selain itu warga Bratang Tangkis menjadi berkembang baik dalam sektor usaha kecil, maupun keterampilan lainnya. [1]

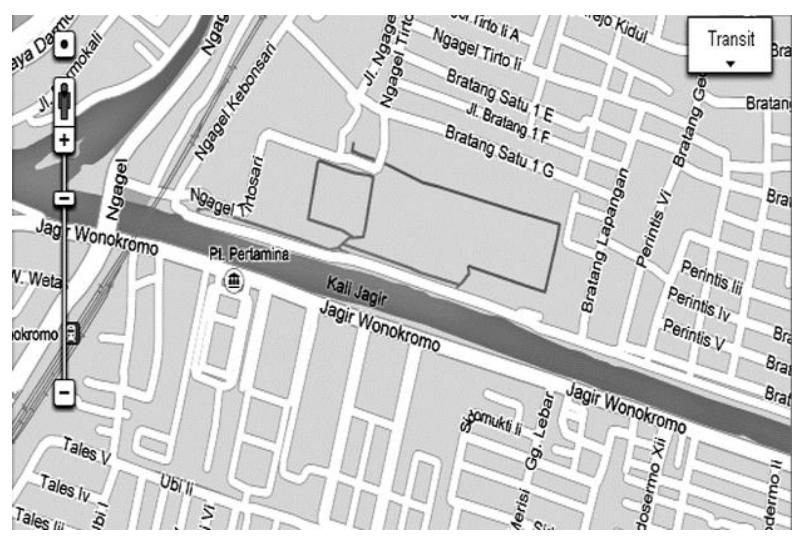

Gambar 1. Peta lokasi kawasan Bratang Tangkis yang berada di sisi sungai (Google Maps)

Kebiasaan warga Bratang Tangkis ini menimbulkan perubahan yang perlahan-lahan pada wajah kampungnya. Wajah unik warga kampung Bratang Tangkis tentu saja tidak berubah secara drastis. Perbaikan rumah yang dikenal sebagai program pembuatan rumah contoh telah dirintis sejak tahun 2005. Hal ini didasari oleh awalnya ketakutan warga untuk digusur dari kampungnya, tetapi pembangunan rumah contoh ini kemudian dikembangkan karena kesadaran warga untuk perlunya kampung yang lebih sehat, hijau, berkelanjutan. Rumah-rumah kampung ini yang tadinya terletak membelakangi sungai kemudian diubah jadi menghadap sungai. Perubahan ini diikuti dengan pembuatan jalan inspeksi selebar 3-5 meter yang mengorbankan atau merombak sebagian besar rumah yang ada. Perombakan ini juga menunjukkan kerelaan hati dan kegotong-royongan warga dalam memperbaiki wajah kampungnya. Ini yang mempesona karena jarang sekali warga kota mau berkorban untuk kecantikan wajah kotanya.

Selain itu kesadaran warga juga tumbuh untuk mengelola sampah organik (dengan komposting keranjang Takakura), mengelola air limbah (dengan tangki septik bersama) dan menanam penghijauan (pertanian kota) di depan rumah. Hal ini meningkatkan keasrian lingkungan kampungnya.
Penataan kampung ini diinspirasikan juga dari lomba desain kampung stren kali yang diadakan Rujak Center dan PWSS pada tahun 2011. Pemenang lomba ini Wiyoga mengusulkan konsep beragam tetapi seragam. Walaupun konsep ini tidak dapat diwadahi secara langsung, namun konsep ini terus dikembangkan oleh warga dengan pembangunan atau perbaikan rumah dengan menggunakan material beton dan bata ekspos.

Sikap warga yang menjaga kali (“jogo kali”) secara aktif juga terlihat pada kegiatan warga yaitu Larung Sungai. Kegiatan larung ini dilakukan setiap tahun oleh warga Bratang yang terpadu dengan warga stren kali lainnya [2]. Larung ini melambangkan kesatuan warga dan sungai yang dijaganya dan rasa syukur warga kepada Tuhan Yang Maha Esa karena rezeki yang diberikan melalui sungai (Kali Wonokromo dan kampungnya).

Larung juga menunjukkan pelestarian seni lokal seperti Remo, nembang, iring-iringan sajen, dan lain-lain yang seringkali sudah ditinggalkan oleh warga kota secara umum. Inilah pesona kampung yang unik dari Bratang. Kesenian warga lainnya ialah keroncong, seniman keroncong Pak Prayit juga tinggal di kampung ini. Seniman ini pernah mewakili Surabaya di Festival Keroncong Sedunia tahun 2009 di Solo. Keroncong ini merupakan alunan musik yang mempesona yang mengiringi suasana sore yang santai di kampung ini. Kesenian lainnya yang ada di kampung ini ialah Jaranan (Kuda Lumping) menunjukkan keberanian, yang asalnya dari Jember dan merupakan warisan seni Jawa Timur.

Selain itu terdapat potensi keindahan lainnya dari Bratang Tangkis ialah nelayan sungai. Sungai yang dijaga juga ialah sungai yang memberikan rejeki buat para nelayan itu. Nelayan-nelayan sungai menggunakan jaring dan pancing untuk menangkap ikan-ikan di sungai yang mengalami pasang naik dan pasang surut. Ikan-ikan ini seringkali hanya dimakan atau dikonsumsi secara lokal di kampung Bratang. Walaupun hidup sebagai nelayan sungai cukup berat, tetapi keluarga keluarga nelayan tetap bertahan untuk menangkap ikan dengan caranya yang unik.

Setelah 10 tahun pengorganisasian warga Bratang Tangkis dalam PWSS, kampung ini berkembang lebih cantik, menarik dan hijau. Hal ini disebabkan oleh keswadayaan, ketulusan dan kegotong royongan warganya inilah yang langka dari warga kota Surabaya secara umum. Hal ini perlu didokumentasikan agar menjadi warisan informasi perkotaan bagi Kampung Bratang Tangkis serta Kota Surabaya. 


\section{ANALISIS KONDISI}

Jumlah komunitas yang dilayani dalam pengabdian masyarakat berupa pelatihan video ini adalah sekitar 10 orang peserta dari kampung Bratang Tangkis. Secara keseluruhan terdapat $429 \mathrm{KK}$ tersebar di RW 12 dan RW 11. Setelah melakukan serangkaian pengamatan, wawancara, hingga kemudian berdiskusi dengan tim, maka disimpulkan bahwa kebutuhan warga ialah kebutuhan untuk mendokumentasikan potensi lingkungan pada kampung Bratang Tangkis secara partisipatif. Setelah didiskusikan dengan LPPM, diusulkan untuk dilakukan pengembangan kemampuan industri kreatif memakai media video di kampung kota, terutama untuk pernikahan dan sejarah kampung. Kegiatan ini terkait dengan pengembangan ekonomi lokal dan seiring dengan strategi pengembangan ekonomi kreatif secara nasional. Dalam kegiatan pelatihan untuk anak-anak muda di Bratang Tangkis ini ditawarkan sebuah program menyangkut hal tersebut.

Untuk materi pelatihan dilakukan shooting video kampung secara partisipatif. Objek yang akan dishooting ialah pernikahan dan event-event penting di kampung. Kemudian akan dilakukan pelatihan untuk transfer video dan editing video ini. Tujuan pembuatan video ini untuk menghasilkan sumber penghasilan baru bagi warga kampung. Selain itu untuk membuat video sejarah kampung yang bisa digunakan sebagai wadah sosialisasi kepada warga di acara-acara penting, membangun kebanggaan akan kampungnya dan membangun generasi aktivis masa depan yang mengerti kondisi kampungnya.

Melanjutkan ide tersebut maka dikembangkan juga kemampuan produksi video pernikahan. Banyaknya warga yang menggelar pernikahan menginspirasi untuk membekali anak-anak muda ini berkreasi untuk mengembangkan kemampuan pribadinya yang bertujuan sebagai potensi ekonomi warga. Hal ini dipilih karena rekomendasi tim LPPM UK Petra.

\section{Persiapan}

Awalnya dilakukan pembicaraan secara informal untuk membahas rencana abdimas ini antara tim dari UK Petra dengan bapak Gatot Subroto, warga Bratang Tangkis pada platform Ayorek! Ayorek! adalah suatu platform yang bertujuan untuk mengumpulkan dan mengorganisasi pengetahuanpengetahuan mengenai Surabaya, serta menampilkannya dalam berbagai format yang menarik dan lebih mudah diakses [3]. Karena itu, Platform Ayorek! ini memang berhasil mengumpulkan berbagai pihak untuk berkolaborasi untuk melakukan pemetaan tentang urban knowledge dan segala bentuk kolaborasi yang terkait.

\section{Pertemuan Awal dan Rekrutmen Warga di Kampung Stren Kali}

Setelah diskusi awal tersebut, dilakukan kunjungan oleh tim UK Petra yang didampingi oleh bapak Gatot Subroto untuk melihat kondisi kampung Bratang Tangkis pada Desember 2012. Dari hasil kunjungan ini dilakukan penyusunan proposal pengabdian masyarakat (abdimas) kepada LPPM pada bulan Desember 2012 - Januari 2013 dengan melibatkan Erandaru yang ahli dalam multimedia, Budi Prasetyadi yang konsentrasinya pada karakter budaya lokal, dan Linda Octavia, arsitek pemerhati kawasan kota.

\section{PELAKSANAAN}

Setelah proposal abdimas disepakati dengan LPPM, maka dilakukan tahapan-tahapan pelaksanaan program ini di laboratorium audio visual DKV. Hal ini dikoordinasikan dengan Erandaru, dan asistennya, Agis Hermansyah.

\section{Workshop Produksi}

Dilakukan dua kali workshop produksi di laboratorium audio visual DKV. Materi yang diajarkan ialah pengenalan kamera, pengenalan sound recording, lighting dan proses shooting. Hal ini dilakukan secara berkelompok dan dengan metode praktek secara langsung mencoba peralatan yang ada. Materi-materi yang diajarkan di antaranya:

- Pengambilan gambar

- Aturan sepertiga untuk shooting

- Aturan head space

- Aturan operasi kamera lainnya

Untuk menghidupkan suasana yang ada, maka dilakukan simulasi resepsi pernikahan yang memakai adat Jawa dan dilakukan oleh peserta pelatihan kemudian direkam dengan video. Diharapkan dengan simulasi ini maka peserta pelatihan dapat mengerti aplikasi.

\section{Produksi Mandiri}

Dilakukan dua kali produksi mandiri di kampung Bratang Tangkis. Karena keterbatasan peralatan, maka shooting hanya dilakukan dengan kamera Mini-DV yang didonasikan oleh Green Impact Indonesia kepada tim masyarakat. Shooting ini di antaranya meliput beberapa kegiatan seperti kegiatan kerja bakti dan perbaikan rumah (rumah contoh). Kendala yang dihadapi pada proses ini 
adalah peralatan sound mic dan lighting tidak tersedia. Keterbatasan alat juga menyebabkan tidak semua peserta pelatihan dapat melakukan produksi mandiri.

Sementara itu, beberapa hasil shooting juga dikumpulkan dari penggalian potensi kampung Bratang Tangkis oleh warga Bratang Tangkis bersama Ayorek! dilakukan pada bulan November sampai Desember 2012. Kegiatan ini difasilitasi oleh Gunawan, anggota tim yang sangat intensif menggarap kawasan Bratang Tangkis sebagai kawasan urban yang harus dibenahi. Beberapa tema yang dikumpulkan ialah meliputi resepsi pernikahan warga, "larung kali", dan nelayan sungai

\section{Workshop Transfer dan Editing Sederhana}

Dilakukan lima (5) kali workshop transfer dan Editing sederhana di laboratorium audio visual DKV. Dalam workshop ini dipelajari penggunaan Adobe Premiere dan Youtube Editor. Dalam 5 pertemuan ini dibahas beberapa materi Adobe Premiere secara umum sebagai berikut:

- Menyusun story board untuk video pernikahan

- Mempersiapkan setting bidang kerja video CD PAL

- Impor data/footage

- Memasukkan data/footage ke dalam timeline

- Mengatur durasi (waktu tampil) footage/data

- Mengatur transisi antar-klip

- Memasang effect pada video

- Memasang suara

- Me-render video pada format Avi

- Membuat teks baru

- Menyimpan teks

- Mengedit teks

- Mengalirkan teks pada path/garis

- Membuat roll dan crawl

Hal terakhir yang juga diajarkan adalah Youtube Editor. Hal ini didasari karena keterbatasan kemampuan para peserta pelatihan untuk memiliki komputer. Software ini bersifat open source karena merupakan online software. Semua video yang akan diedit akan di-upload dahulu ke Youtube. Materimateri lain untuk Youtube Editor yang dapat digunakan ialah:

- Memasukkan data/footage ke dalam timeline

- Mengatur durasi (waktu tampil) footage

- Mengatur transisi antar-klip

- Membuat dan mengedit teks

Selain mengajarkan teknik-teknik di atas para peserta pelatihan diwajibkan untuk membuat film pendek sepanjang 10-20 menit. Hal ini dilakukan agar peserta dapat mempraktekkan teknik-teknik di atas. Materi-materi ini didapati dalam bentuk buku yang dibeli dari toko buku. Buku ini kemudian difotokopi untuk para peserta pelatihan.

Ada empat film pendek yang dihasilkan dengan judul "Nelayan Sungai", "Kawinan Warga", "Kerja Bakti", dan "Larung". Setiap proyek ini disusun oleh sebuah kelompok beranggotakan 2 orang peserta pelatihan.

\section{Editing Mandiri}

Para peserta pelatihan diwajibkan untuk meneruskan proyek di warnet atau menggunakan komputer di rumah masing-masing. Ternyata terdapat beberapa kesulitan dalam penggunaan komputer ini terkait dengan kapasitas komputernya. Hal ini menunjukkan bahwa ternyata terdapat kesulitan untuk mengembangkan industri kreatif pembuatan video pernikahan ini. Selain itu juga, ternyata terlihat Youtube Editor ini sulit diterapkan karena kecepatan bandwidth yang ada juga tidak memadai. Akibatnya peserta pelatihan video yang tidak memiliki komputer yang memadai harus mencari donor dari pihak-pihak lain untuk membeli komputer dalam pembuatan video ini.

\section{Workshop Penutup}

Workshop penutup dilakukan dengan memberikan rekomendasi untuk penyusunan film secara keseluruhan. Storyboard sangat diperlukan untuk mengembangkan kemampuan produksi dan editing video. Hal ini harus dikembangkan dulu sebelum shooting. Selain itu, disepakati bahwa pelatihan ini dapat dilanjutkan pada tahun berikutnya jika masih diperlukan.

\section{PRESENTASI HASIL PELATIHAN}

\section{Pemutaran Film di Kampung Bratang Tangkis dan C2O Library}

Untuk melakukan sosialisasi tentang hasil dokumentasi video ini maka dilakukan pemutaran film di Kampung Bratang Tangkis dan Perpustakaan C20 yang terletak di Jn. Cipto 20 Surabaya. Hal ini dilakukan dengan bekerjasama dengan Paguyuban Warga Strenkali Surabaya, Perpustakaan C2O, Platform Ayorek!, Rujak Center, dan Urban Poor Concortium (UPC). Hal ini dilakukan untuk mengapresiasi program-program yang pernah dilakukan dan mengangkat dampak dari abdimas UK Petra terhadap masyarakat di Kampung Bratang Tangkis.

\section{Pendokumentasian}

Pelaporan dilakukan untuk mendokumentasikan proses abdimas ini. Berbagai media video, foto dan deskripsi digunakan untuk membantu pelaporan ini. 


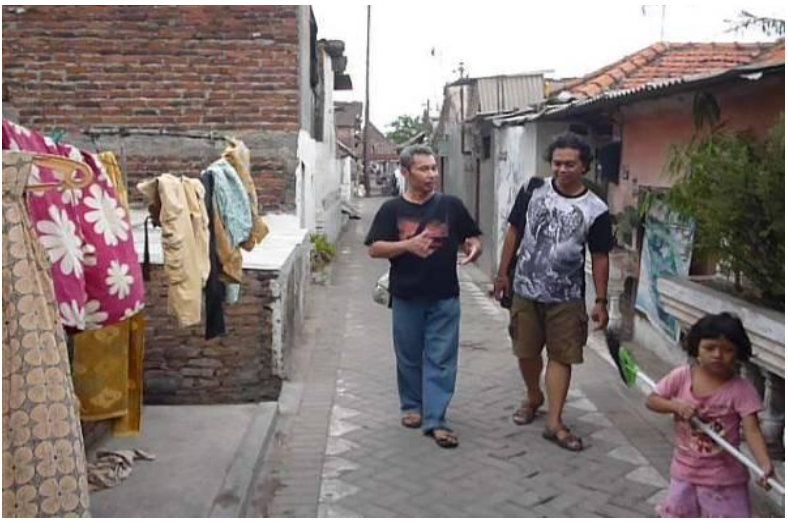

Gambar 2. Kunjungan ke lapangan dalam persiapan abdimas

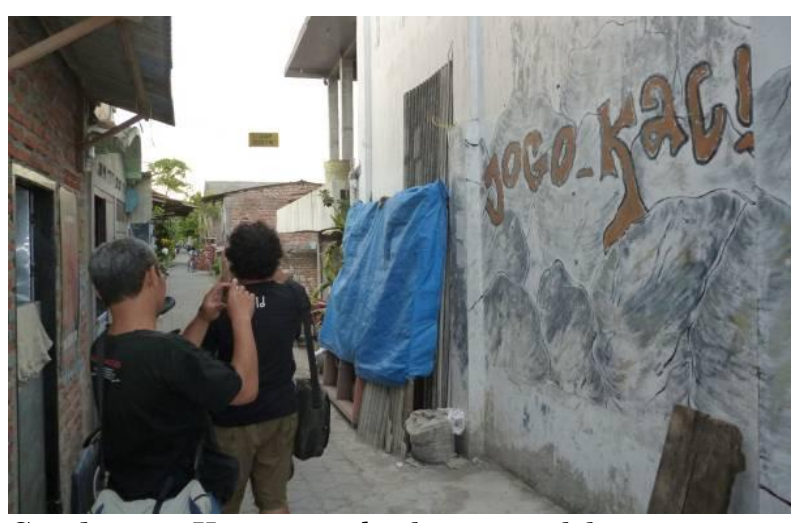

Gambar 3. Kunjungan ke lapangan dalam persiapan abdimas

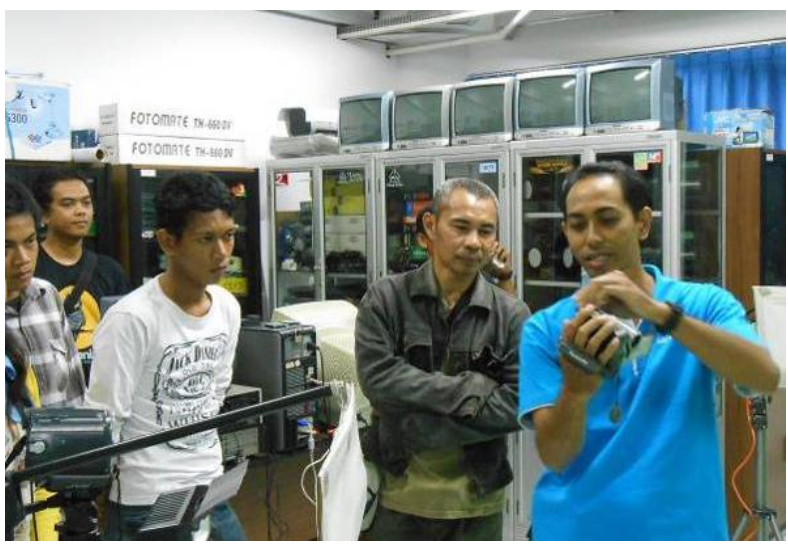

Gambar 4. Pengenalan kamera video

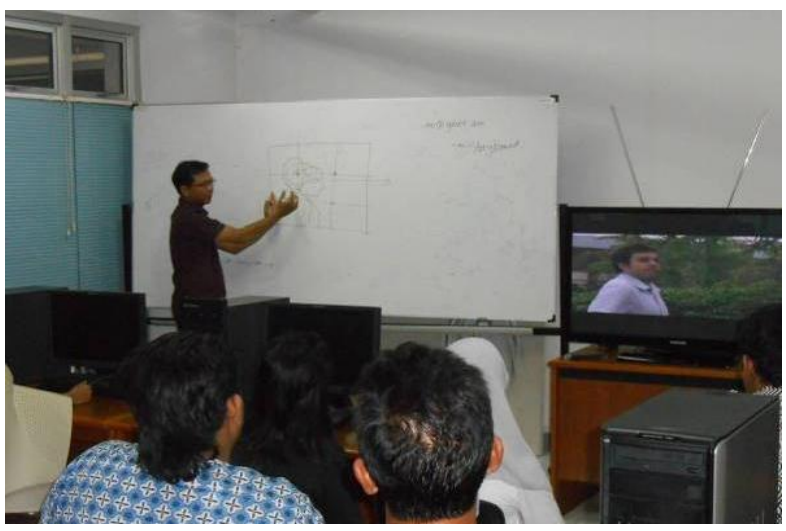

Gambar 5. Pengenalan produksi video

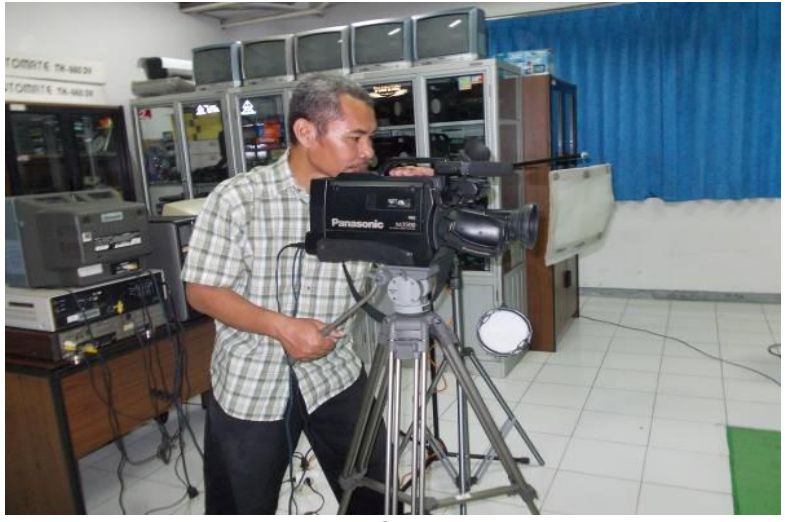

Gambar 6. Pelatihan produksi video

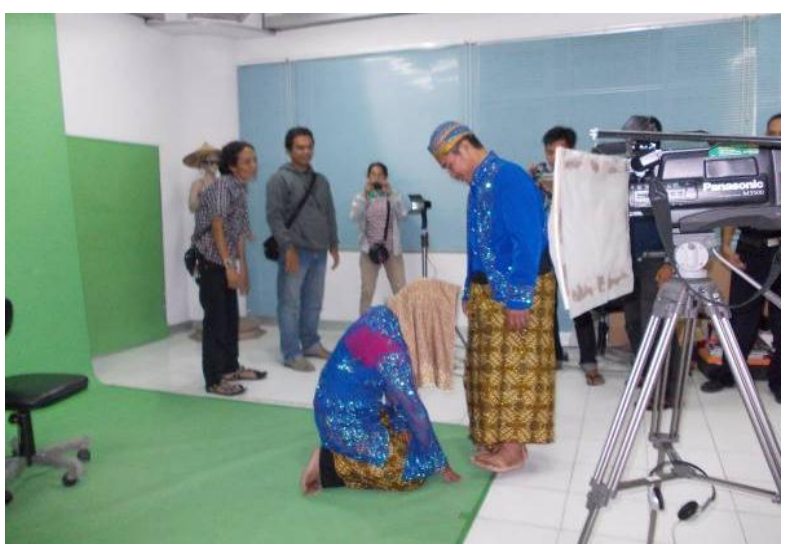

Gambar 7. Pelatihan produksi video

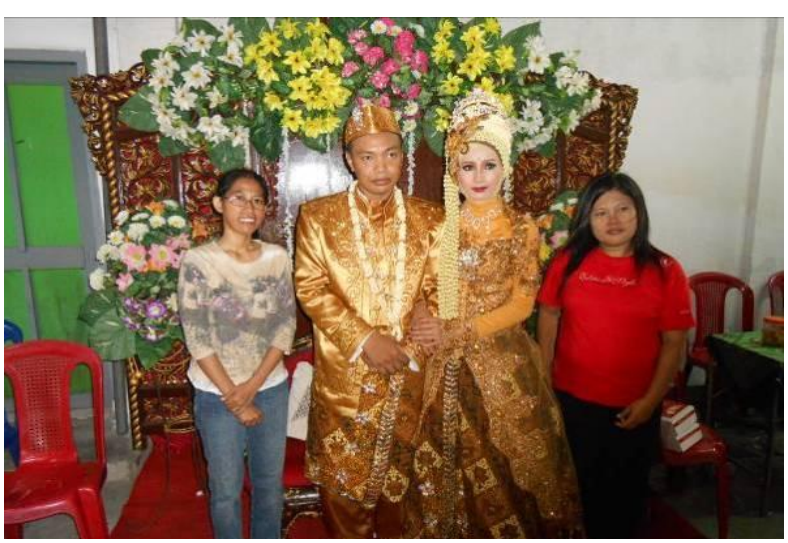

Gambar 8. Praktik produksi video mandiri di kampung yang menyelenggarakan pernikahan

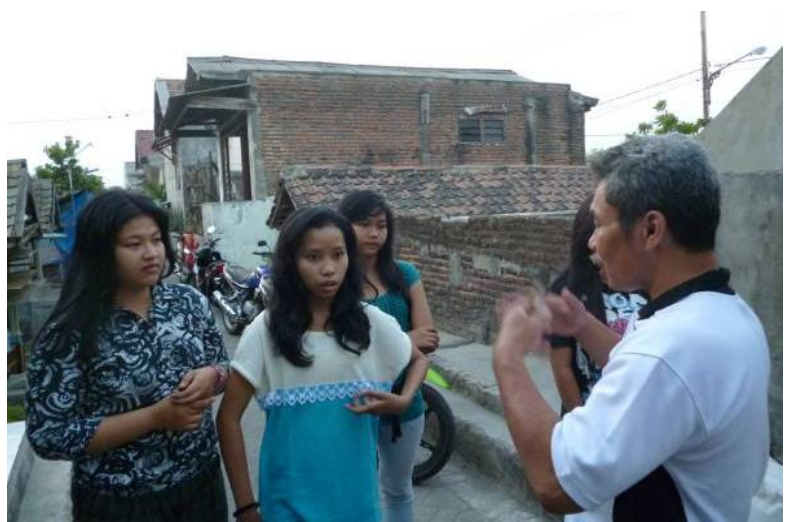

Gambar 9. Produksi video di kampung dengan fokus sejarah kampung 


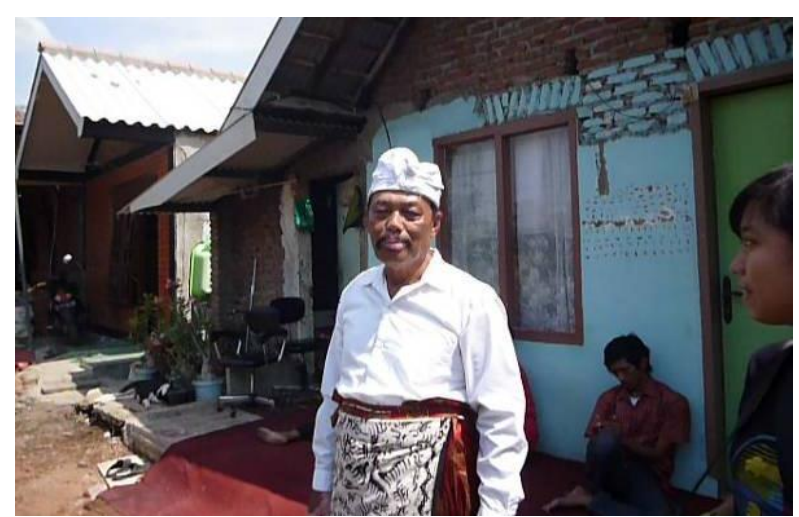

Gambar 10. Produksi video di kampung dengan fokus "larung kali"

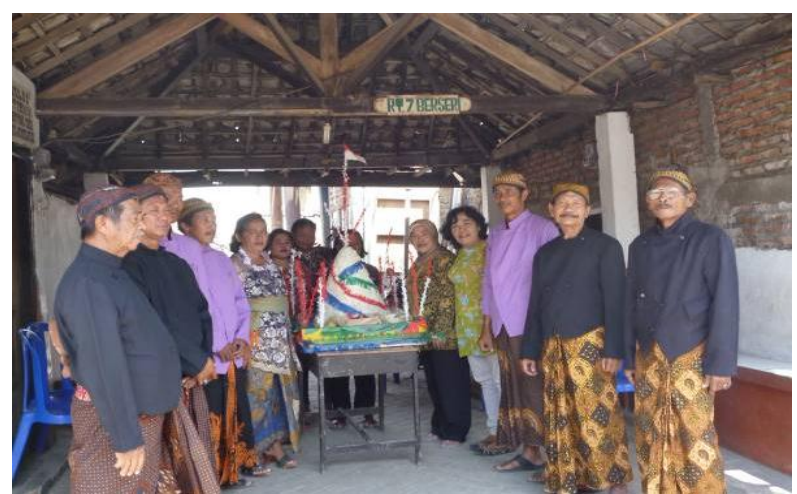

Gambar 11. Produksi video di kampung dengan fokus "larung kali"

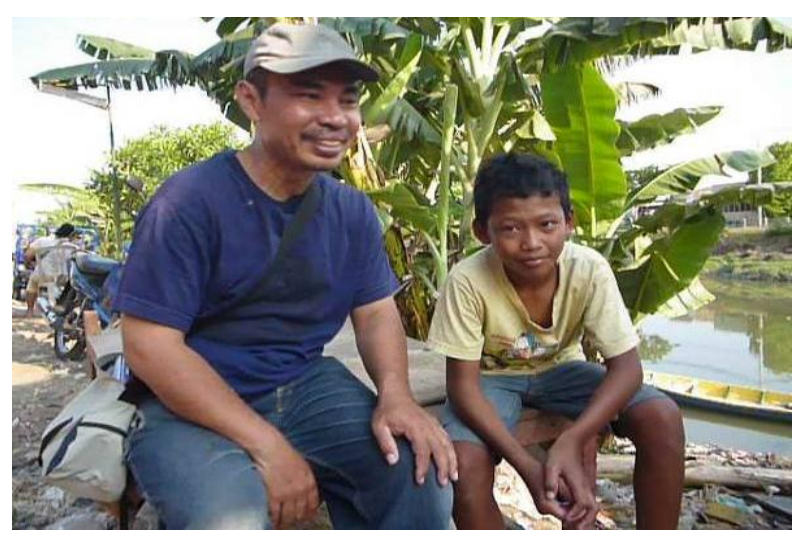

Gambar 12. Produksi video di kampung dengan fokus nelayan sungai

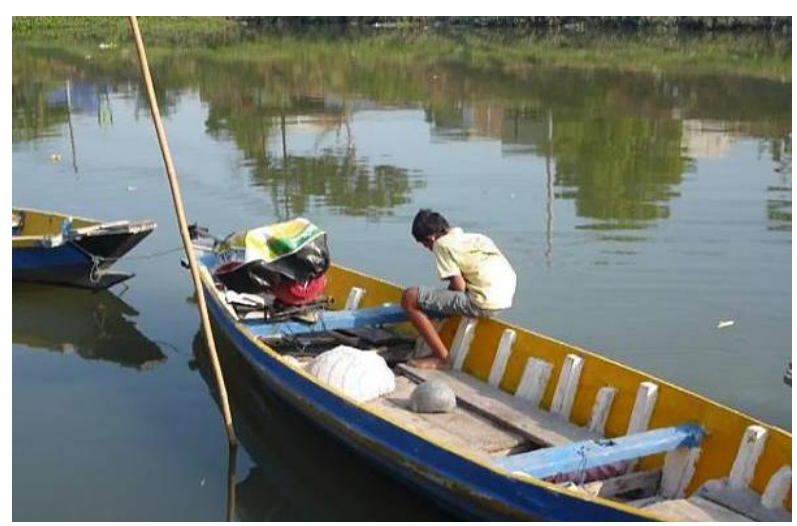

Gambar 13. Produksi video di kampung dengan fokus nelayan sungai

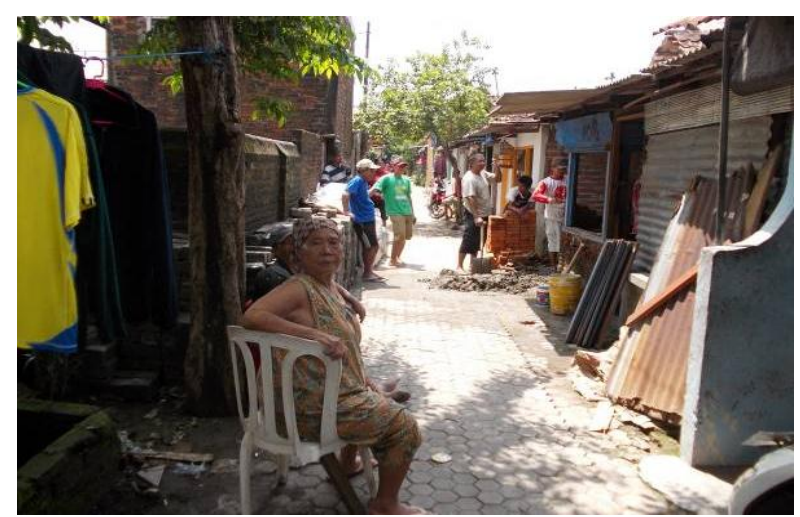

Gambar 14. Produksi video mandiri di kampung dengan fokus kerja bakti

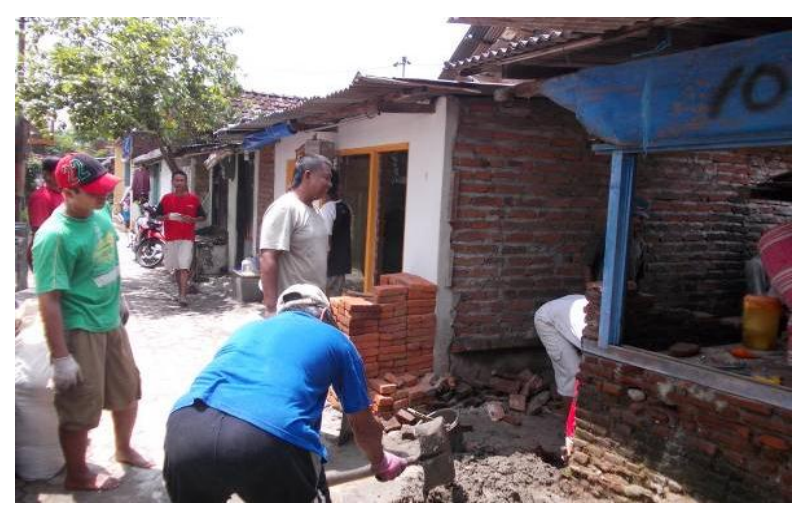

Gambar 15. Produksi video mandiri di kampung dengan fokus kerjabakti

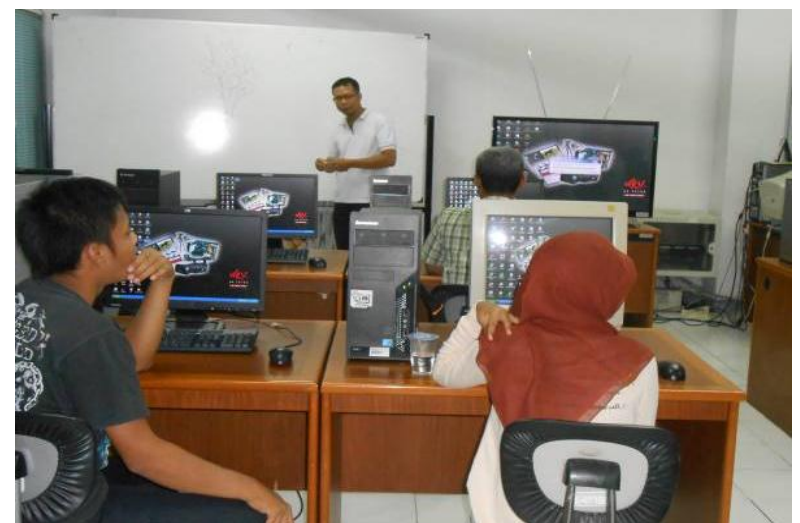

Gambar 16. Pelatihan video editing

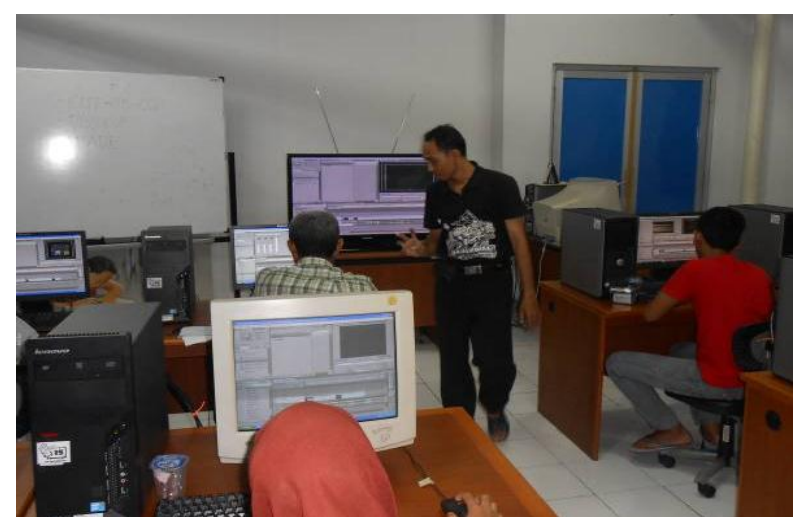

Gambar 17. Pelatihan video editing 


\section{PEMBAHASAN}

Kegiatan ini bermanfaat untuk:

a. Warga kampung Bratang Gede

- Mampu membuat video pernikahan dan sejarah kampung lainnya

- Menjadi bangga atas potensi kampungnya

- Memperkenalkan citra positif kampung Bratang Tangkis di mata penduduk Surabaya

- Menciptakan industri kreatif.

b. Program Studi Arsitektur UK Petra

- Mampu membuat model dokumentasi permukiman yang partisipatif

- Mampu mengembangkan model Service Learning pengembangan kampung kota

c. Program Studi Desain Komunikasi Visual UK Petra

- Mampu mengembangkan pengembangan industri kreatif yang dapat diterapkan di masyarakat umum

- Mampu mengembangkan abdimas yang efektif

- Mampu mengembangkan software open source untuk produksi video

d. Ilmu Pengetahuan

- Mengembangkan metode partisipatif dalam pembuatan sejarah kampung.

Selain itu juga diusulkan beberapa rekomendasi untuk kegiatan selanjutnya yaitu sebagai berikut:

- Menyadari untuk membuat industri kreatif membutuhkan infrastruktur kamera video dan komputer yang memiliki spesifikasi yang memadai. Ternyata dari beberapa peserta pelatihan memang tidak memiliki kamera dan komputer tidak dapat menerapkan hasil dari pelatihan ini karena keterbatasan ini. Sebaliknya rekanrekan lainnya dapat menerapkan hasil pelatihan ini karena sudah memiliki kamera dan laptop atau komputer. Karena itu hasilnya cukup baik.

- Dibutuhkan software open source untuk video editing yang dapat digunakan secara maksimal. Software ini dapat dikembangkan dengan kerjasama antara Program Studi DKV dan Teknik Informatika.

\section{KESIMPULAN}

Didapati bahwa memang kebutuhan warga untuk mendokumentasi kehidupan kampung kota terutama peristiwa pernikahan memerlukan kemampuan produksi dan editing video. Hal ini dapat dipenuhi dengan pelatihan seperti di atas. Namun kendala yang dihadapi warga yang mengikuti pelatihan ini adalah keterbatasan alat sehingga tidak dapat menerapkan kemampuan mereka secara optimal. Meski begitu pelatihan ini bermanfaat bagi rekan-rekan yang memiliki fasilitas dan menjadi industri kreatif dalam skala mikro. Diperlukan juga software open source yang dapat digunakan untuk masyarakat yang dapat dikembangkan oleh Universitas Kristen Petra.

\section{DAFTAR PUSTAKA}

[1] http://strenkalisurabaya.blogspot.com/2012_10_ 01_archive.html;

[2] http://ayorek.org/2013/05/pesona-kampungpinggir-kali/).

[3] http://ayorek.org/about/ 